\title{
POTENCY OF MAKING THE CHEMICAL MANGANESE DIOXIDE (CMD) FROM EAST NUSA TENGGARA PYROLUSITE
}

\author{
POTENSI PEMBUATAN MANGAN DIOKSIDA DARI PIROLUSIT \\ NUSA TENGGARA TIMUR
}

\author{
DESSY AMALIA, SARIMAN and AZHARI \\ R\&D Centre for Mineral and Coal Technology \\ Jalan Jenderal Sudirman 623 Bandung 40211 \\ Phone (+6222) 6030483, Fax. (+6222) 6003373 \\ e-mail: dessy@tekmira.esdm.go.id
}

\begin{abstract}
Chemical manganese dioxide has not yet commercially developed in Indonesia. It is supplied by import sector. The fact that Indonesia has manganese resources as many as $60,893,820$ tons is inconsistent with above condition. Research on CMD making employed pyrolusite as the raw material with size of $100+150$ mesh. The material was then reacted with sulfuric acid $6 \%$ and various concentration of molasses as reductant from 10, 20, 30, 50 and $100 \%$. The manganese sulfate leachate was then purified using sodium hydroxide and then filtered to have a nonferrous manganese sulfate. The Mn was precipitated from manganese sulfate using sodium bicarbonate. The precipitated manganese carbonate was then calcined at $600^{\circ} \mathrm{C}$ by injecting the air at various flow rates $(100,200,300,400$ $\mathrm{cc} /$ minute) and different calcination time (2, 3, 4 hours) to get manganese dioxide. The best extracted Mn reached $97.58 \%$ using $50 \%$ of molasses as a reductant. The precipitation of manganese carbonate had produced sodium carbonate as an impurity. The calcination had not yet changed the manganese carbonate into manganese dioxide due to extremely high calcination temperature.
\end{abstract}

Keywords: pyrolusite, molasses, precipitation, calcination

\begin{abstract}
ABSTRAK
Mangan dioksida belum diusahakan di Indonesia dan kebutuhannya dipenuhi dari impor. Hal itu bertentangan dengan fakta bahwa Indonesia memiliki sumber daya bijih mangan sebanyak 60.893 .820 ton. Penelitian pembuatan mangan oksida menggunakan bijih pirolusit berukuran $-100+150$ mesh dan direaksikan dengan asam sulfat $6 \%$ serta molases sebagai reduktor dengan variasi konsentrasi 10, 20, 30, 50, $100 \%$ telah dilakukan. Larutan mangan sulfat hasil pelindian dimurnikan dengan natrium hidroksida untuk memisahkan besi terlarut dan kemudian disaring untuk mendapatkan larutan mangan sulfat bebas besi. Mangan diendapkan menggunakan sodium bikarbonat. Presipitat mangan karbonat dikalsinasi pada $600^{\circ} \mathrm{C}$ dengan mengalirkan udara menggunakan laju alirdan waktu yang bervariasi masing-masing secara berurutan adalah 100, 200, 300, 400 cc/menit dan 2, 3, 4 jam untuk menghasilkan mangan dioksida. Ekstraksi mangan terbaik yang diperoleh sebesar 97,58\% menggunakan molase 50\% sebagai reduktor. Pada presipitasi mangan karbonat dihasilkan natrium karbonat sebagai pengotor. Kalsinasi mangan karbonat belum mengubah material tersebut menjadi mangan dioksidakarena temperatur kalsinasi yang dilakukan terlalu tinggi.
\end{abstract}

Kata kunci: pirolusit, molases, presipitasi, kalsinasi

\section{INTRODUCTION}

Manganese is the twelfth most common element in earth's crust and fourth ranked after iron, aluminum and copper as widely used metal. More than $90 \%$ manganese is used as metallurgical product in steel manufacturing. The second largest is used as 
a dry cell battery (Webb, 2008). Those added values of manganese have not yet applied in Indonesia as reported by Ministry of Energy and Mineral Resources (Anon, 2014).

Indonesia has manganese resources as many as $60,893,820$ tons (Anon, 2015). The manganese had previously been exported without any processing until the Ministry of Energy and Mineral Resources Regulation No. 8, 2015 issued a regulation regarding the minimum limit of major element percentage for metal commodities. Therefore some processing efforts have to be accomplished to fulfill the regulation.

Methods for processing the ore usually depend on the ore grade. High grade manganese ores are generally treated to produce ferromanganese (FeMn) and silicon manganese (SiMn) through pyrometallurgy technique while the low grade ores are processed through hydrometallurgy method into chemical manganese dioxide (CMD) or electrolytic manganese dioxide (EMD) to replace the roasting step by reductive leaching (Sumardi, 2013).

Reductive leaching is a leaching process in reductive condition. The condition has to be applied in order to transform Mn(IV) from manganese ore into $\mathrm{Mn}$ (II) as seen in Figure 1. It is shown that the manganese ore leaching has to be managed in reductive condition within acid circumstances or low $\mathrm{pH}$. The kinetics of manganese reductive leaching is controlled by diffusion through insoluble layer of the associated minerals (Su et al., 2010).

Leach liquors resulted from leaching usually dissolve undesirable elements. Some treatments are needed to increase the liquor concentration through purification to eliminate or separate undesirable metals. Several options of purification process include precipitation, cementation, solvent extraction, ion exchange etc. Carbonate precipitation of manganese solution using ammonium carbonate is suitable to separate nickel and cobalt as well as manganese in ammine complexes solution to solid carbonates (Baba et al., 2014).

Some researches regarding reductive leaching of manganese ore especially pyrolusite have been conducted using sulfuric acid with different reducing agent or additive. Sponge iron is proved to be a good additive by Bafghi et al. (2008). The efficiency of Mn dissolution after 10-minutereaction was $98 \%$ at room temperature using the particle size of $-250+150 \mu \mathrm{m}$ and the $\mathrm{H}_{2} \mathrm{SO}_{4}$ to $\mathrm{MnO}_{2}$ molar ratio of 0.8 as well as sulfuric acid to $\mathrm{MnO}_{2}$ molar ratio of 3.0. The result has a better performance than that of previous researchers that used ferrous iron as the additive.

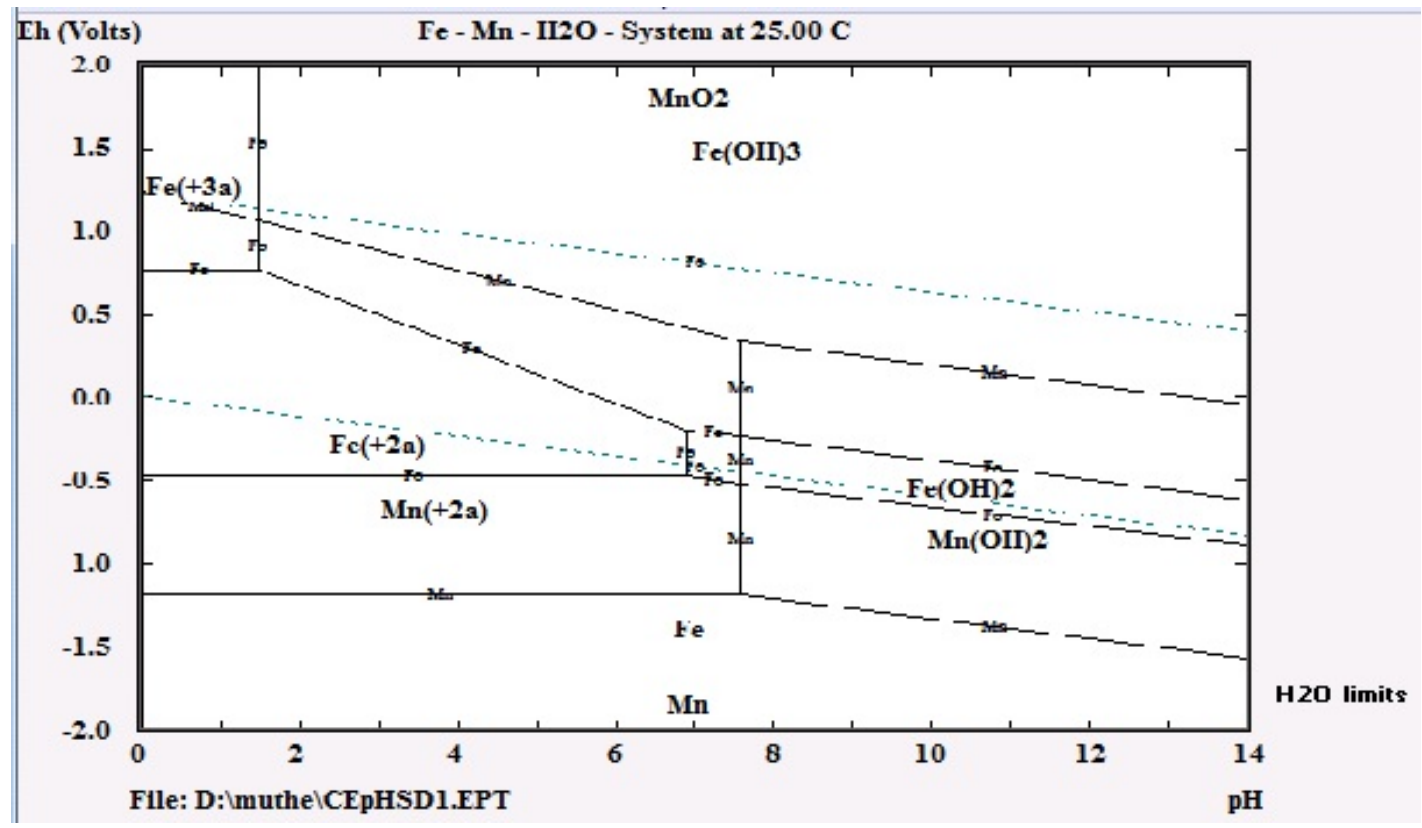

Figure 1. Eh- pH system of $\mathrm{Mn}-\mathrm{Fe}-\mathrm{H}_{2} \mathrm{O}$ at $25^{\circ} \mathrm{C}$ (Sumardi, 2013) 
Another research on manganese reductive leaching from pyrolusite using sulfuric acid as solvent had also been conducted by Nayl et al. (2011). The leaching was performed optimum condition using $\mathrm{H}_{2} \mathrm{O}_{2}$ as a reductant. The optimum condition of the leaching was achieved at $40^{\circ} \mathrm{C}$ for 90 minutes using $4.0 \mathrm{M} \mathrm{H}_{2} \mathrm{SO}_{4}$ and $0.8 \mathrm{M} \mathrm{H}_{2} \mathrm{O}_{2}$ on particle size of $44-37 \mu \mathrm{m}$ pyrolusite. The manganese leaching efficiency was $92 \%$.

Various reductants have been applied but the organic reductant has approved to be simple and efficient to leach pyrolusite (Su et al., 2009). The organic one is also environmental friendly. Some of them that can be used as reducing agent are molasses, hay, corn cob and sawdust (Sumardi, 2013). The use of corncob as reductant in reductive pyrolusite leaching had been conducted by Aliet al. (2106). The siliceous manganese ore were diluted in 1.9 $\mathrm{mol} / \mathrm{dm}^{3}$ sulfuric acid solution. Best manganese extraction was $92.8 \%$ and accomplished in 60 minutes at $90^{\circ} \mathrm{C}$ and 4 grams of corncob.

Su et al. (2009) had conducted reductive pyrolusite leaching using sulfuric acid as a solvent and molasses of alcohol wastewater as the reductant. The optimum condition for such a leaching was performed by $1.9 \mathrm{~mol} / \mathrm{L}$ $\mathrm{H}_{2} \mathrm{SO}_{4}$ and $2.0 \mathrm{~mL} / \mathrm{g}$ of alcohol-wastewater molasses based on $\mathrm{Mn}$ content in pyrolusite. The reductive leaching conducted at $90^{\circ} \mathrm{C}$ for 120 minutes and resulted Mn efficiency more than93\%. While, the recoveries of Fe and $\mathrm{Al}$ about 37 and $25 \%$ respectively. Another research dealing with pyrolusite reductive leaching was conducted using molasses from sugar production waste. The highest percentage of manganese dissolution reached up to $95.33 \%$ using condition $70^{\circ} \mathrm{C}$-temperature, $6 \%$-sulfuric acid $\left(\mathrm{H}_{2} \mathrm{SO}_{4}\right), \quad 10 \%$-percent solid, $100 \mathrm{~g} / \mathrm{L}$ molasses, 200-rpm and 6-hour leaching time. Chemical reaction of the leaching was as follows (Sumardi, 2013):

$$
\begin{aligned}
& \mathrm{C}_{6} \mathrm{H}_{12} \mathrm{O}_{6}+12 \mathrm{MnO}_{2}+24 \mathrm{H}^{+} \rightarrow 6 \mathrm{CO}_{2}+ \\
& 12 \mathrm{Mn}^{2+}+18 \mathrm{H}_{2} \mathrm{O}
\end{aligned}
$$

Previous research (Su et al., 2009; Sumardi, 2013) proved that molasses is a good reductant. However some improvements are required to get a higher extraction percentage. This research tried to seek a better molasses composition to have higher manganese dissolution efficiency than previous ones using molasses as a reductant. Nevertheless, the manganese sulfate production using molasses as a reductant has not yet available to be applied for making the chemical manganese dioxide. The potency of chemical manganese dioxide production using molasses as a reductant through hydrometallurgy method needs to be proved.

\section{METHODOLOGY}

The experiments used manganese ore from East Nusa Tenggara. The ore was dried by oven at $110^{\circ} \mathrm{C}$ for 24 hours then was prepared through sampling and milling to get representative samples size of $-100+150$ mesh. The sample was then reacted within 2mole/L sulfuric acid and various molasses concentration (10;20;30; 50; $100 \%)$ as reductant at $90^{\circ} \mathrm{C}$ in 6 hours. Equipments for process was shown in Figure 2. The leachate from filtered leaching solution heated at $70^{\circ}$ Calong with $10-\% \mathrm{NaOH}$ until pH 5-6as seen in Figure 3 to precipitate the ferrous hydroxide. Then the solution was filtered to separate ferrous hydroxide. Remained solution was heated to $50^{\circ} \mathrm{Cand}$ added with sodium carbonate to $\mathrm{pH} 9$ to get precipitated manganese carbonate. The manganese carbonate was then calcined in tube furnace at $600^{\circ} \mathrm{C}$ with various air rate $(200 ; 300 ; 400)$ $\mathrm{cc} / \mathrm{minute}$ for 2 hours. The best air rate was used for next experiments using various calcination temperatures. Figure 4 showed the flowchart of the process.

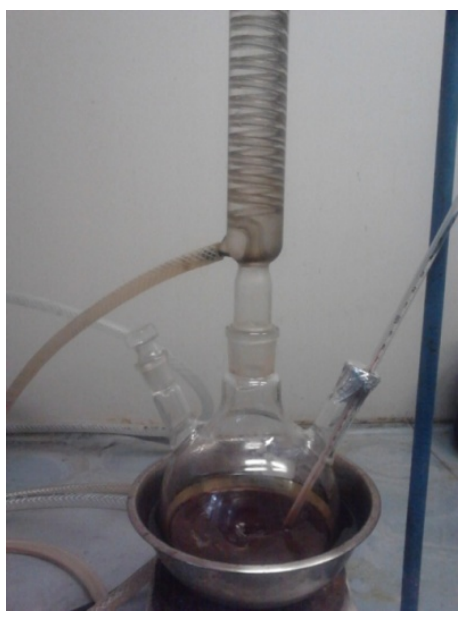

Figure 2. Leaching process of pyrolusite 
INDONESIAN MINING JOURNAL Vol. 19, No. 2, June $2016: 79$ - 87

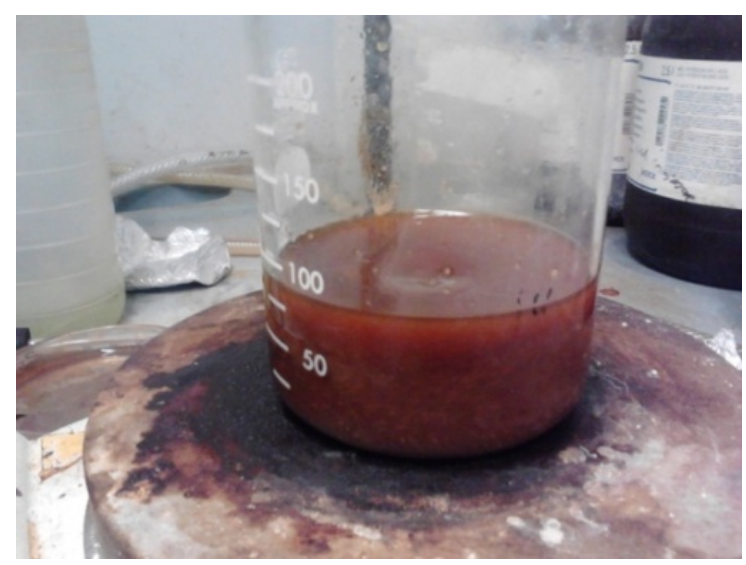

Figure 3. Ferrous precipitation from leaching solution
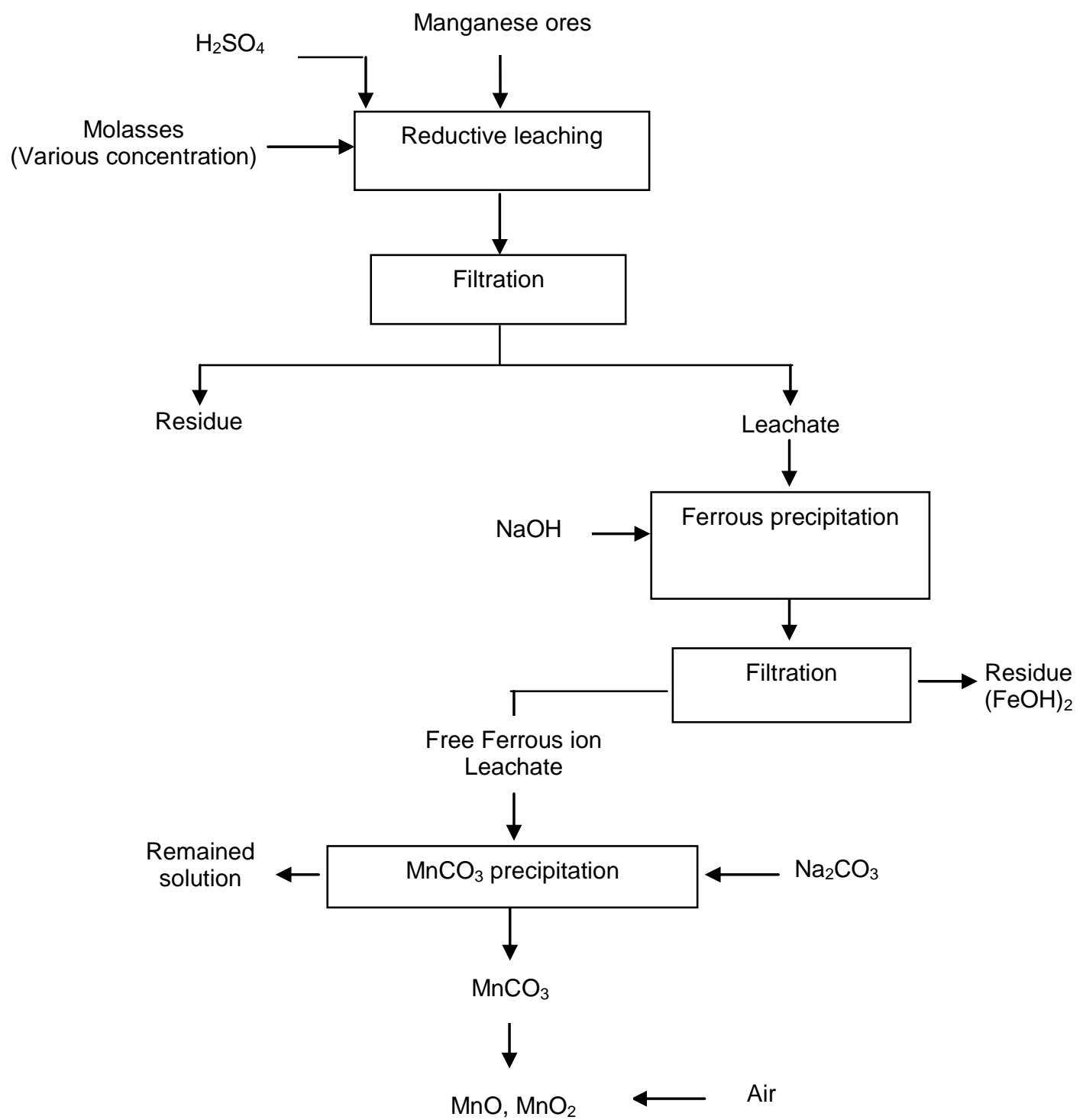

Figure 4. The flowchart regarding the process to get manganese dioxide 


\section{RESULTS AND DISCUSSION}

XRD analyses of manganese ore showed (Figure 5) pyrolusite $\left(\mathrm{MnO}_{2}\right)$ and manganite $\left(\mathrm{Mn}(\mathrm{OH})_{3}\right.$ along with quartz $\left(\mathrm{SiO}_{2}\right)$. However the presence of potassium was also detected by X-ray mapping (SEM-EDS method) test result as shown in Figure 6. Through SEM photo-micrograph test, it is known that manganese mineral is associated with silicate mineral.
Mineral composition is supported by chemical composition as presented in Table 1. It is showed that the manganese as the primary component followed by $\mathrm{SiO}_{2}$ as the major impurity. The amount of $\mathrm{Al}, \mathrm{Mg}$, and $\mathrm{Ca}$ present the silicate content in the ore. Manganese contents in the ore used as a basic calculation for sulfuric consumption. Result of the manganese ore leaching is presented in Table 2 and illustrated in Figure 7.

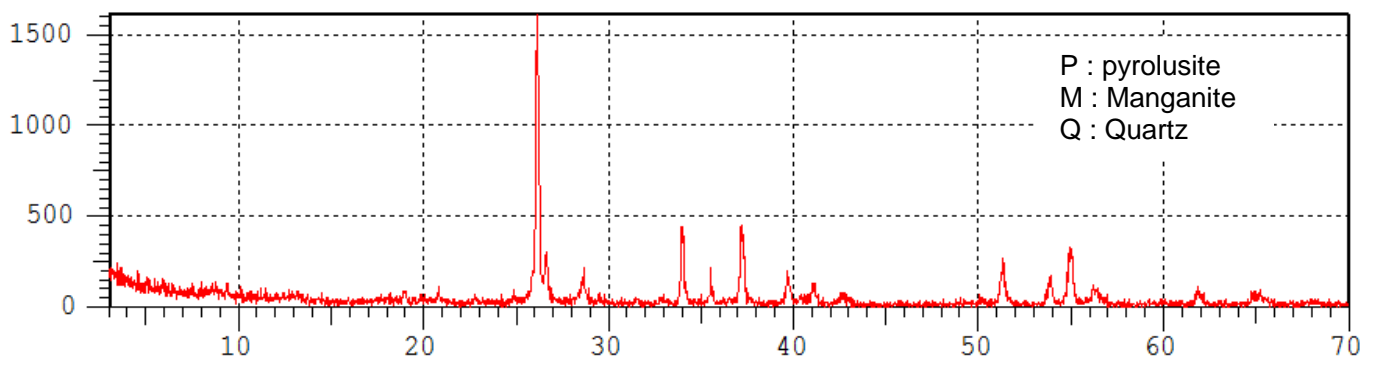

Figure 5. XRD pattern of manganese ore

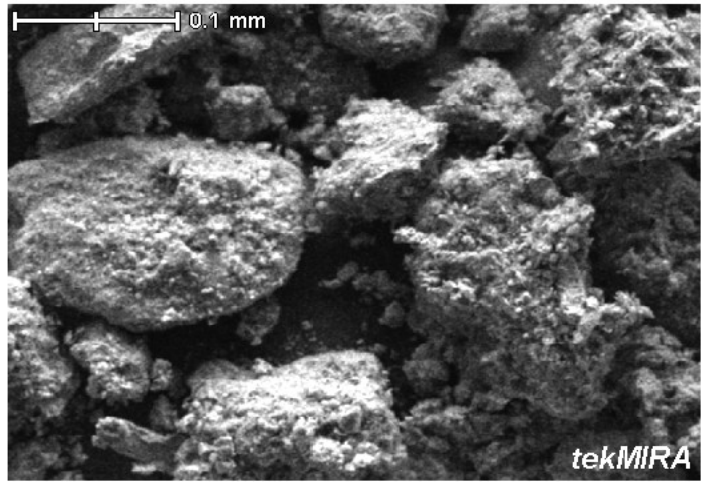

(a)
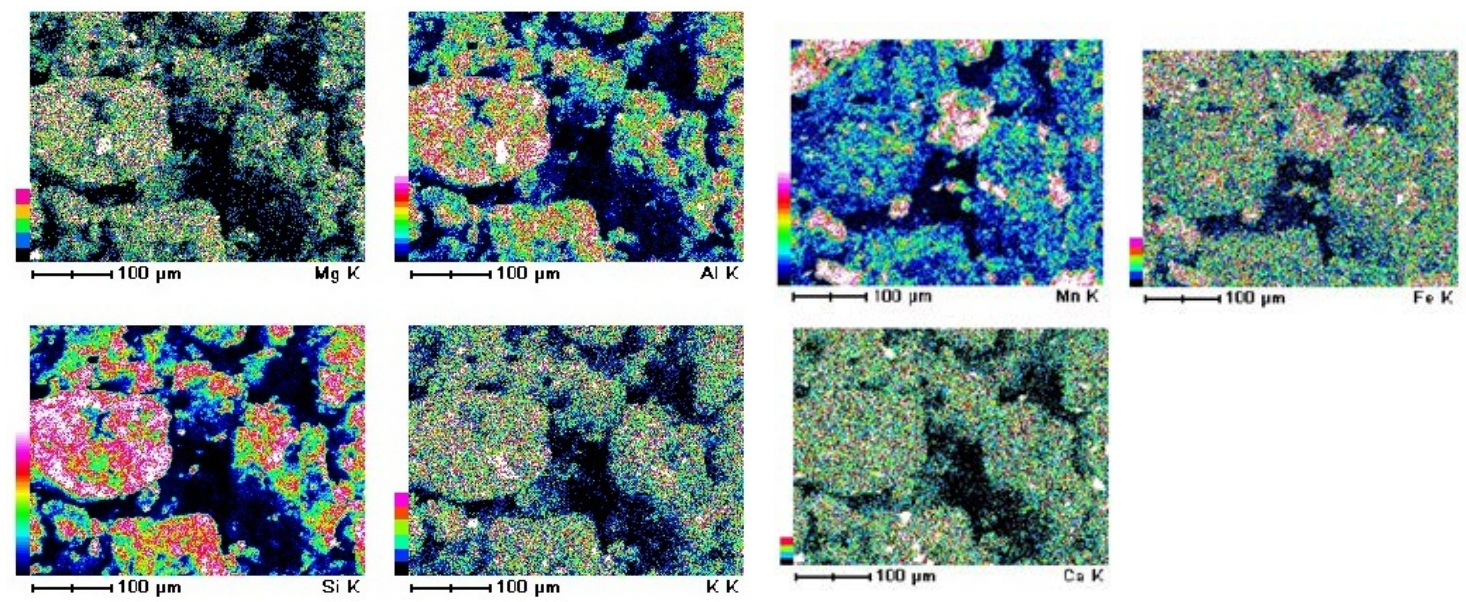

(b)

Figure 6. (a) SEM photo-micrograph of manganese ore and (b) X-Ray mapping analysis of the ore 


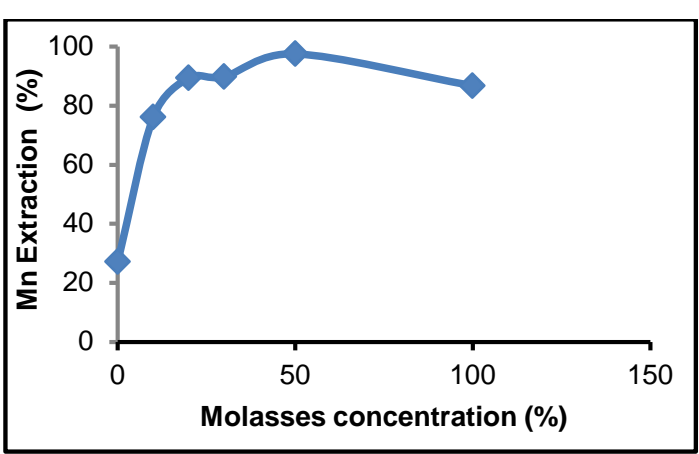

Figure 7. Mn extraction behavior versus molasses concentration

Table 1. Chemical composition of manganese ore

\begin{tabular}{cc}
\hline Element/oxide & Amount (\%) \\
\hline $\mathrm{Mn}$ total & 43.8 \\
$\mathrm{MnO}_{2}$ & 40.6 \\
$\mathrm{MnO}$ & 23.4 \\
$\mathrm{SiO}_{2}$ & 14.61 \\
$\mathrm{Al}_{2} \mathrm{O}_{3}$ & 2.74 \\
$\mathrm{Fe}$ & 1.43 \\
$\mathrm{~K} \mathrm{O}$ & 1.42 \\
$\mathrm{BaO}$ & 1.69 \\
$\mathrm{MgO}$ & 0.23 \\
$\mathrm{CaO}$ & 0.50 \\
$\mathrm{Cu}$ & 0.029 \\
\hline
\end{tabular}

Table 2. Result of manganese ore leaching using various molasses concentrations in 2.0 moles/Liter $\mathrm{H}_{2} \mathrm{SO}_{4}$

\begin{tabular}{cc}
\hline $\begin{array}{c}\text { Molasses } \\
\text { Concentration (\%) }\end{array}$ & Mn Extraction (\%) \\
\hline 0 & 27.09 \\
10 & 76.10 \\
20 & 89.42 \\
30 & 89.85 \\
50 & 97.58 \\
100 & 86.79 \\
\hline
\end{tabular}

The results proved that leaching condition was supposed to be reductive as shown in Eh- pH system of $\mathrm{Mn}-\mathrm{Fe}-\mathrm{H}_{2} \mathrm{O}$ at $25^{\circ} \mathrm{C}$ (Figure 1). It is confirmed that without molasses the extraction percentage was poor compares to others concentration. The result also proved that molasses is a good reductant for manganese ore reductive leaching. $\mathrm{Mn}$ extraction improved as the molasses concentration increased to $50 \%$ $(97.58 \%)$ and decreased when $100 \%$ concentration of molasses were added. The excessive amount of molasses will trigger others element besides $\mathrm{Mn}$ reduction; the elements consumed more sulfuric acid. Constant amount of sulfuric acid would reduce $\mathrm{Mn}$ dissolution rate than that of previous molasses concentration.

The best $\mathrm{Mn}$ extraction which is used $50 \%$ of molasses concentration was purified from ferrous ion with sodium hydroxide $(\mathrm{NaOH})$ addition to precipitate the ferrous. Remained solution was added with sodium carbonate $\left(\mathrm{Na}_{2} \mathrm{CO}_{3}\right)$ to precipitate the manganese carbonate as visualized in Figure 8 . Confirmation of the precipitated mineral composition was conducted through XRD analysis as shown at Figure 9 that affirmed the precipitate was manganese carbonate.

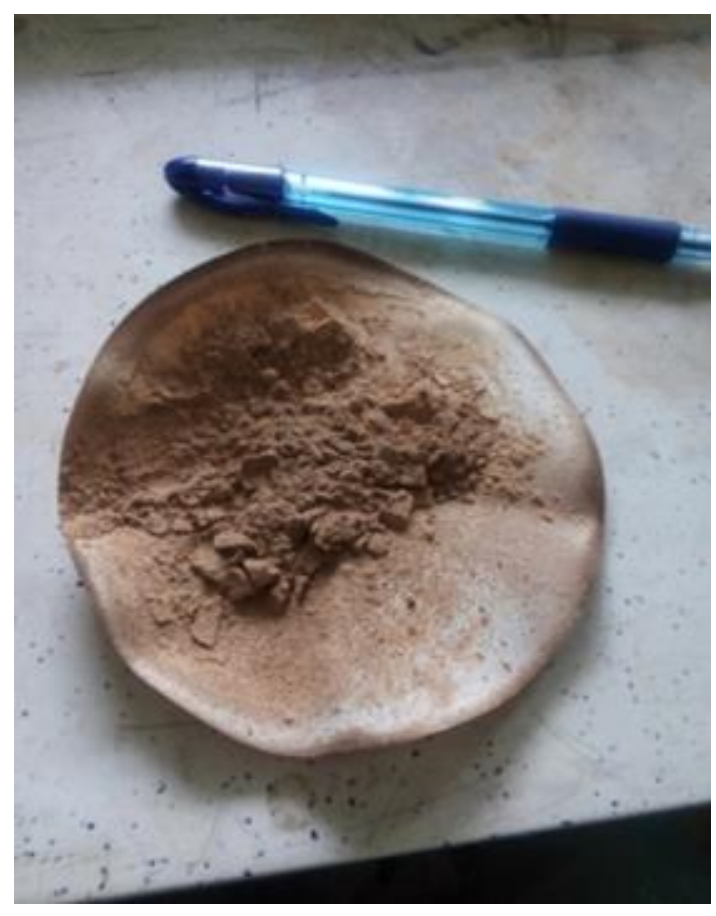

Figure 8. Precipitated manganese carbonate 


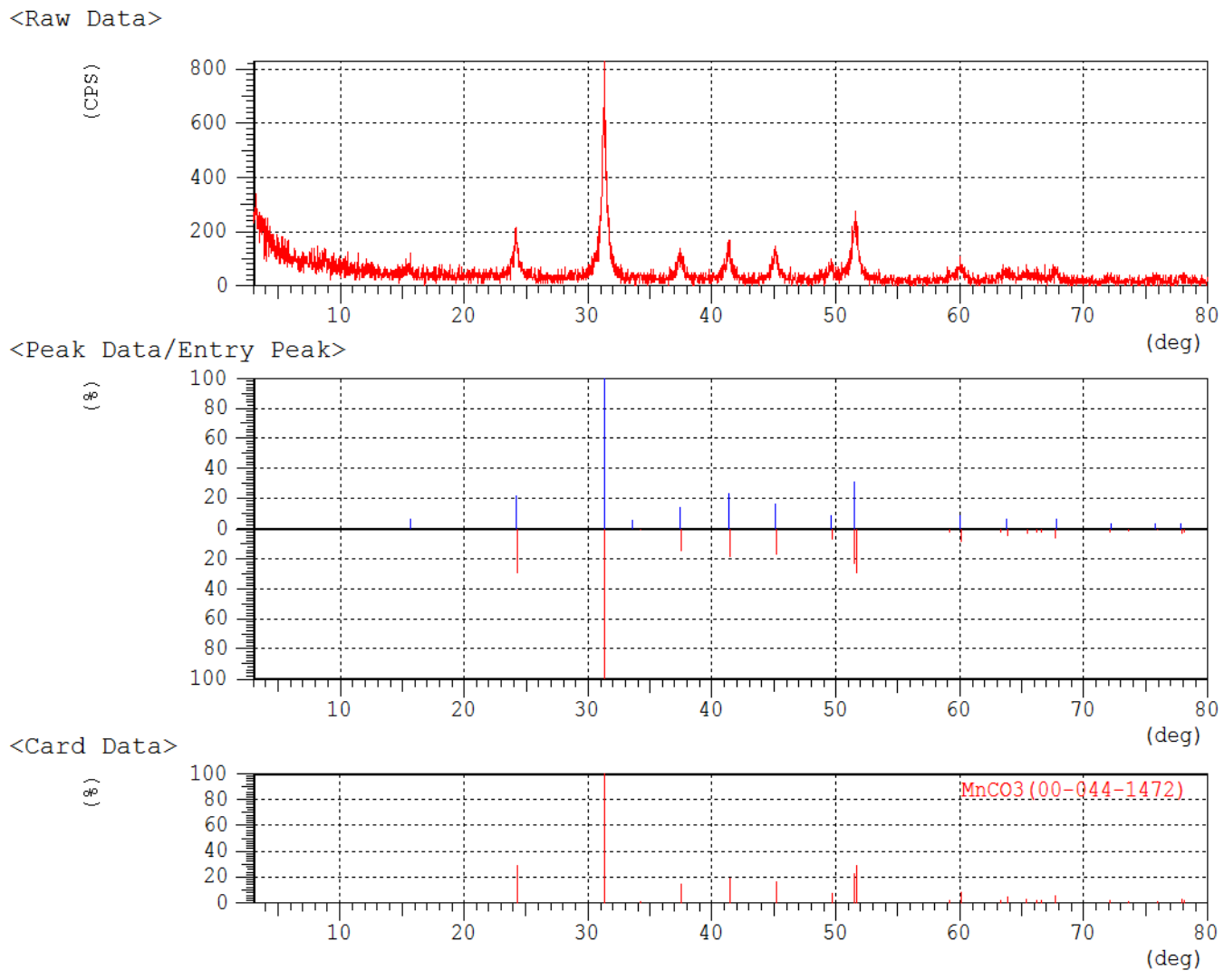

Figure 8. XRD analysis of precipitated manganese carbonate

In terms of making CMD, the manganese carbonate was calcined in a tube furnace equipped with a compressor to supply the air. The product was shown in Figure 10. Calcination was performed firstly at $600^{\circ} \mathrm{C}$ with various air flow rates. As seen in Table 3 , the $\mathrm{MnO}_{2}$ content under condition of 300 $\mathrm{cc} /$ minute air injection is bigger therefore it continued to perform at various temperatures as seen in Table 4. Different temperatures of calcination would produce different $\mathrm{MnOx}$ crystal form along with $\mathrm{MnO}$ and $\mathrm{MnO}_{2}$. The possible $\mathrm{MnOx}$ phase that can be produced were $\mathrm{Mn}_{3} \mathrm{O}_{4}, \mathrm{Mn}_{5} \mathrm{O}_{8}$ even $\mathrm{Mn}_{2} \mathrm{O}_{3}$ (Ren et al., 2014).

According to TGA test for $\mathrm{MnO}_{2}$ and $\mathrm{MnCO}_{3}$ under air and argon atmosphere, the $\mathrm{MnCO}_{3}$ would transform to $\mathrm{MnO}$ at $450^{\circ} \mathrm{C}$ while $\mathrm{MnO}_{2}$ to $\mathrm{Mn}_{2} \mathrm{O}_{3}$ at $550^{\circ} \mathrm{C}$ and further transformation into $\mathrm{Mn}_{3} \mathrm{O}_{4}$ at $950^{\circ} \mathrm{C}$ (Saputra et al., 2013). The XRD test of manganese carbonate calcination at $600^{\circ} \mathrm{C}$ resulted transformation into manganese oxidehaussmanite $\left(\mathrm{Mn}_{3} \mathrm{O}_{4}\right)$ containing sodium sulfate $\left(\mathrm{Na}_{2} \mathrm{SO}_{4}\right)$ as an impurity (Figure 10). The presence of sodium sulfate was considered to occur during precipitation of manganese carbonate. The precipitation of such a material was illustrated as follows:

$\mathrm{MnSO}_{4}+\mathrm{Na}_{2} \mathrm{CO}_{3} \rightarrow \mathrm{MnCO}_{3}+\mathrm{Na}_{2} \mathrm{SO}_{4}$

while illustration for calcination process was shown below:

$2 \mathrm{MnCO}_{3}+\mathrm{O}_{2} \rightarrow 2 \mathrm{MnO}_{2}+2 \mathrm{CO}_{2}$

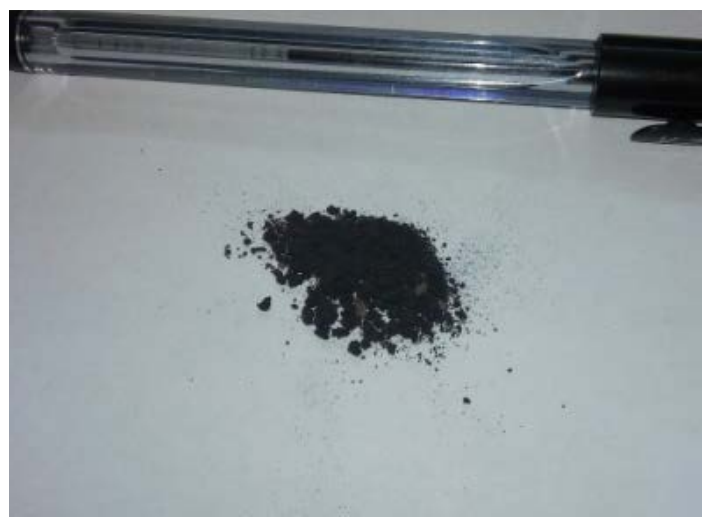

Figure 9. Calcined manganese carbonate 
INDONESIAN MINING JOURNAL Vol. 19, No. 2, June 2016 : 79 - 87

Table 3. Mn content in calcined manganese carbonate at $600^{\circ} \mathrm{C}$ for 2-hour reaction with various air flow rate $(200,300,400 \mathrm{cc} /$ minute $)$

\begin{tabular}{cccc}
\hline \multirow{2}{*}{ Compounds } & \multicolumn{3}{c}{ Content (\%) } \\
\cline { 2 - 4 } & $200 \mathrm{cc} /$ minute & $300 \mathrm{cc} /$ minute & $400 \mathrm{cc} /$ minute \\
\hline Mn Total & 55.2 & 56.7 & 56.68 \\
$\mathrm{MnO}$ & 43.16 & 40.44 & 44.8 \\
$\mathrm{MnO}_{2}$ & 34.78 & 40.17 & 34.78 \\
\hline
\end{tabular}

Table 4. Mn content in calcined manganese carbonate for 2-hour leaching using $300 \mathrm{cc} / \mathrm{minute}$ of air with various temperature $\left(600,700,800^{\circ} \mathrm{C}\right)$

\begin{tabular}{lllll}
\hline \multirow{2}{*}{ Compounds } & \multicolumn{3}{c}{ Content (\%) } \\
\cline { 2 - 5 } \multicolumn{1}{c}{$600^{\circ} \mathrm{C}$} & \multicolumn{2}{c}{$700^{\circ} \mathrm{C}$} & $800^{\circ} \mathrm{C}$ \\
\hline Mn Total & 56.7 & 54.47 & 55.82 \\
$M n O$ & 40.44 & 44.57 & 46.19 \\
$\mathrm{MnO}_{2}$ & 40.17 & 31.73 & 31.73 \\
\hline
\end{tabular}

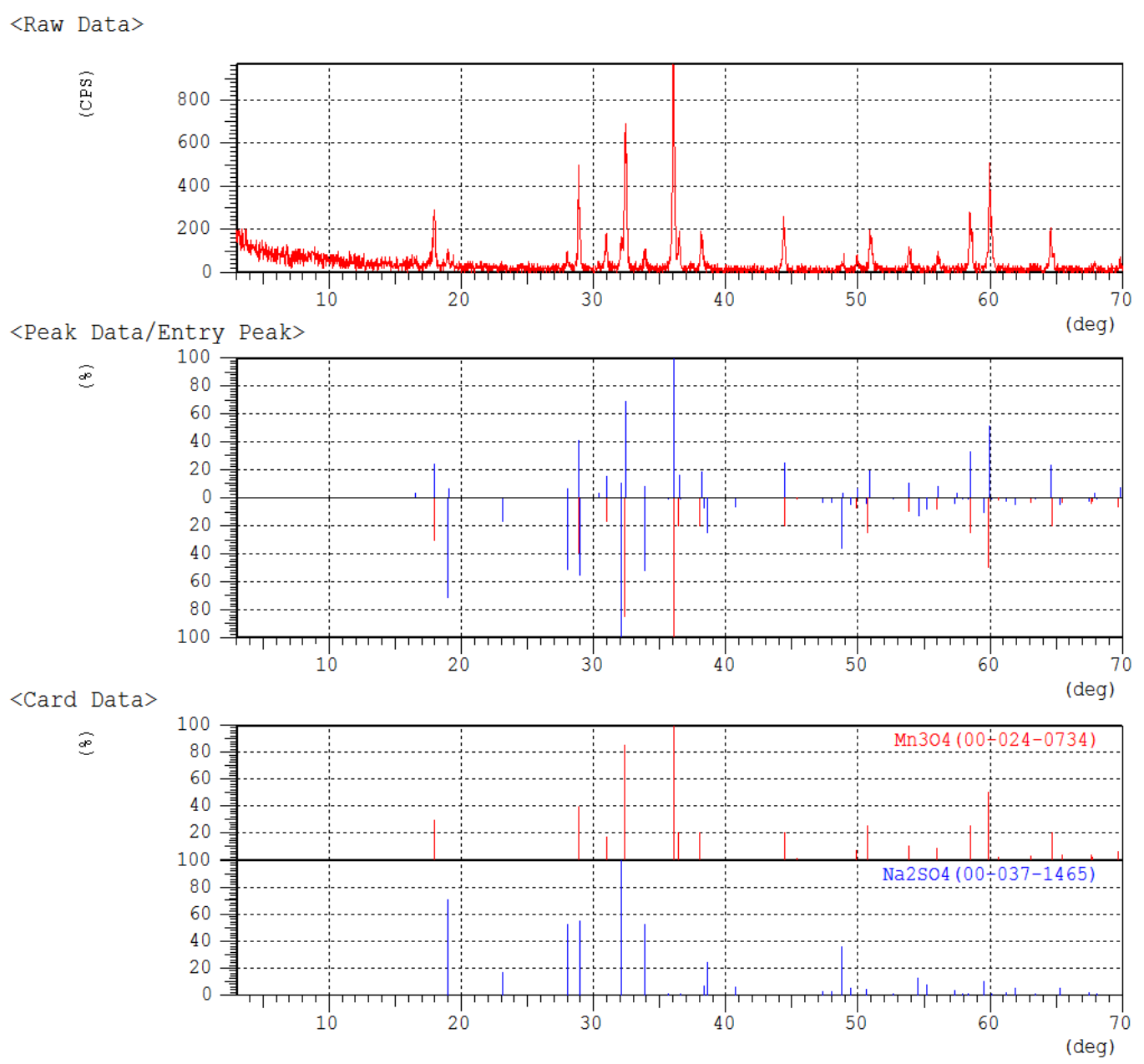

Figure10. XRD test on calcined manganese carbonate at $600^{\circ} \mathrm{C}$ for 2-hour leaching using $300 \mathrm{cc} /$ minute air as the oxidant. 


\section{CONCLUSIONS}

Molasses has a good ability as a reductant. Optimum amount of $50 \%$ concentration of molasses can extract $97.58 \%$ of $\mathrm{Mn}$ from pyrolusite. Precipitation of $\mathrm{Mn}$ from manganese sulfate leachate can be conducted using sodium bicarbonate but yielded sodium sulfate as an impurity. Therefore, it is suggested to use ammonium carbonate to precipitate the manganese in terms of avoiding the formation of sodium carbonate. The change of manganese carbonate into manganese dioxide has not yet succeeds but it turns into haussmanite because the calcination temperature that applied was too high. It is suggested to apply calcination temperatures below $600^{\circ} \mathrm{C}$.

\section{ACKNOWLEDGEMENT}

The authors would like to acknowledge the Ministry of Energy and Mineral Resources for the research funding. It is also granted to Mr. Slamet Sumardi, a researcher at Indonesian Institute of sciences, for providing the molasses.

\section{REFERENCES}

Ali, S., Iqbal, Y., Farooq, U., and Ahmad S., 2016. Leaching of manganese ores using corn cob as reductant in $\mathrm{H}_{2} \mathrm{SO}_{4}$ solution. Physicochem. Probl. Miner. Process. 52(1), p. 56-65.

Anonymous, 2015. Pemutakhiran data dan neraca sumber daya mineral status 2015. Executive summary, Kementrian Energi dan Sumber Daya Mineral.

Anonymous, 2014. Arah Kebijakan Alokasi Sumberdaya Mineral \& Batubara Untuk Kebutuhan Bahan Baku Sebagai Substitusi Impor. Disampaikan pada Rapat kerja Kementrian Perindustrian Tahun 2014.Direktorat Pembinaan Pengusahaan Mineral, Direktorat Jenderal Mineral dan Batubara, Kementrian Energi dan Sumberdaya Mineral (KESDM).

Baba, A.A., Ibrahim,L., Adekola, F., Balez, R.B., Ghosh, W.K., Sheiks A.R., Pradhan, S.R., Ayanda, O.S., Folorinshoz, I.O.,
2014. Hydrometallurgical Processing of Manganese Ores: A Review. Journal of Minerals and Materials Characterization and Engineering, 2, p. 230-247.

Bafghi M.S, Zakeri, A., Ghasemi, Z., Adeli, M., 2008. Reductive dissolution of manganese ore in sulfuric acid in the presence of iron metal. Hydrometallurgy 90 , p. 207-212.

Nayl, A.A., Ismail, I.M., and Aly, H.F., 2011. Recovery of pure $\mathrm{MnSO}_{4} \cdot \mathrm{H}_{2} \mathrm{O}$ by reductive leaching of manganese frompyrolusite ore by sulfuric acid and hydrogen peroxide. International Journal of Mineral Processing vol. 100, issues 34, p. 116-123.

Ren, C., Zhou L., Shang H. And Chen Y, 2014. Effect of preparation method on the performance of $\mathrm{Pd}-\mathrm{MnOx} / \mathrm{y}-\mathrm{Al}_{2} \mathrm{O}_{3}$ monolithic catalysts for ground - level $\mathrm{O}_{3}$ decomposition. Chinese Journal of Catalysis 35, p. 1883-1891.

Su H., Wen. Y., Wang F., Li Z. And Tong Z., 2009. Leaching of pyrolusite using molasses alcohol wastewater as a reductant. Minerals Engineering 22, p. 207-209.

Su H., Liu, H., Wang F., Lu, X., Li Z. And Wen, $Y$., 2010. Kinetics of reductive leaching of low-grade pyrolusite with molasses alcohol wastewater in $\mathrm{H}_{2} \mathrm{SO}_{4}$. Chinese Journal of Chemical Engineering, 18(5), p. $730-735$.

Saputra, E., Syaifullah, M., Hongqi, S., Ha-Ming, A., Moses O, T. And Shaobin, W., 2013. Manganese oxides at different oxidation states for heterogeneous activation of peroxymonosulfate for phenol degradation in aqueous solutions. Applied Catalysis B: Environmental. 142-143, p. 729-735.

Sumardi, Slamet, 2013. Pelindian Bijih Mangan dari Nusa Tenggara Timur dengan Menggunakan asam Oksalat dan Molases Sebagai Agen Pereduksi dan Sintesis Serbuk Mangan Dioksida dengan Metode Hidrotermal. Tesis, Institut Teknologi Bandung

Webb, T.C., 2008. Manganese. New Brunswick Department of Natural Resources; Minerals, Policy and Planning Division, Mineral Commodity Profile, No.1, 8 p. 
